\title{
Effect of intercropping patterns and nitrogen fertilization levels on yield and yield components of maize and soybean
}

\author{
Gadallah, R.A. and A.M.Gabra* \\ Crop Intensification Research Department* Food Legume Res. Dept., Field Crop Research Institute, \\ Agricultural Research Center, Giza, Egypt
}

\begin{abstract}
A field experiments was carried out at Sers El-Lian Agriculture Research Station Monofiya Governorate during summer seasons 2010 and 2011 to study the effect of nitrogen fertilizer levels and intercropping patterns on yield and yield attributes of maize with soybean intercropping. A split-plot design was used the main plot contains three nitrogen fertilizer were 90,105 and $120 \mathrm{~kg} \mathrm{~N} / \mathrm{fad}$. and the sub plot include three intercropping patterns $\left(\mathrm{P}_{1}\right)(100 \%$ maize $+25 \%$ soybean $),\left(\mathrm{P}_{2}\right)(100 \%$ maize $+50 \%$ soybean $)$ and $\left(\mathrm{P}_{3}\right)(100 \%$ maize $+75 \%$ soybean) with three replications.

\section{The results could be summarized as follows:}

Grain yield/fad. of maize increased by increasing nitrogen fertilizer levels, while decreased by increased plant density of soybean from $25 \%$ to $75 \%$. Seed yield/fad. of soybean increased by increasing nitrogen fertilizer levels and plant density from $25 \%$ to $75 \%$ of solid.

The highest of land equivalent ratio (LER) gave 1.56 and 1.57 and land equivalent coefficient (LEC) produced 0.60 and 0.61 when observed intercropping pattern (100\% maize+ $75 \%$ soybean) and nitrogen fertilizer level $120 \mathrm{~kg} \mathrm{~N} /$ fad. in the first and the second seasons, respectively. The aggressivity (Agg) of soybean was dominant while maize was dominated. The highest of competition ratio (CR) was soybean while lowest of (CR) was maize. The highest values monetary advantage index (MAI) were 2549.15 and 3088.71 and monetary equivalent ratio (MAR) were 1.23 and 1.37 when intercropping pattern (100\% maize $+25 \%$ soybean) and nitrogen fertilizer level $120 \mathrm{~kg} \mathrm{~N} / \mathrm{fad}$. in the first and the second seasons, respectively.
\end{abstract}

Keyword: Intercropping patterns, maize, soybean, competitive relationships.

\section{Introduction}

Intensification of agricultural will result in greater production and income per unit area/year. Multiple cropping systems (sequential cropping and intercropping) may be one of the most important means for intensifying the agriculture system. This is on obligate task in area (Francis 1986). Intercropping is recommended to increase total agriculture products in Egypt (Mettwelly 1999)

Soybean is the most important grain legume crop in the world in terms of total production, international and trade. Soybean seeds contain from 18.0 to $23.0 \%$ oil and 38 to $54 \%$ protein. In Egypt soybean acreage has declined during the last twenty year from 150 thousand fad in 1985 to about 17 thousand fad with total of 25.94 thousand ton of seeds in 2011 season (Agricultural Statistics 2011). This is mainly due to competition with other summer crops (corn, rice etc.,) and high production costs. Panhwar et al (2004) revealed that intercropping of soybean in maize rows did not show any adverse effect on maize plant height, 1000 grain weight as well as grain yield of maize. However, maize under monoculture recorded greater grain yield/ha, soybean planted alone gave better performance in respect of seed yield/ha and yield contributing parameters. While seed and after yield contributing parameters of soybean were significantly affected in intercrop treatments due to competition with main crop. Solank et al (2011) recorded that maize+ soybean intercropping significantly reduced grain yield of maize by 17.3 to $12.6 \%$ as compared with that of solid maize.

Undie et al (2012) reported that intercropping maize with soybean reduced maize compared with sole crop values. Similarly soybean number of branches/plant and seed yield reduced below their sole crop values when intercropping with maize. Shivay and Singh (2003) found that the yield attributing parameters (plant height, branches and pods/ plant, seed/pod, seed weight/plant, 100-seed weight) and yield increased with increasing nitrogen. Undie et al (2010) found that application of $100 \mathrm{~kg}$ N/ha to maize, increased 100-grain weight. Similarly application $100 \mathrm{~kg} \mathrm{~N} / \mathrm{ha}$ to soybean increased number of pods/plant and 100 seed weight by 53 to $16 \%$ over no nitrogen application.

Abd-El-Lateef (1988) found that intercropping pattern 2:2 gave the highest maize 
yield especially when maize was sown at $40 \mathrm{~cm}$ between hills. Intercropped cultures led to taller soybean plant than solid cultures.

Mettwally et al (2009 a) found that the highest intercropped maize grain yield/plant was obtained by growing two maize ridges alternating with four soybean ridges $(2: 4)$ as compared with the other cropping systems, while, the solid planting maize gave the highest grain yield/fad.

Vega et al (2001) reported indicated that efficient use of solar energy for photosynthesis is important for plant growth and survival, especially in low height environments caused by using any intercropping pattern.

Penetrated height intensity through intercrops is potentially influenced by spatial arrangement of intercropping patterns; soybean can grow as a companion crop with maize, either between maize hills on the same rows or interplant on separate rows. On the other hand corn (Zea Mays L.) is one of major summer cereal crop consider acreage and total production. However, it occupies almost 2.157 million fad with total of 7.21 million tons of grain in 2011 season. (Agricultural Statistics 2011)

Toaima (2006) stated that plant height, number of fruiting branches, number of pods, seed yield/plant, weight of 100 seed and seed yield/fad were affected significantly by intercropping patterns. Intercropping pattern $100 \%$ maize $+37.5 \%$ soybean gave the highest values, whereas the lowest values were recorded by $100 \%$ maize+ 12.5 soybean.

Mettwally et al (2007) demonstrated that intercropping pattern produced taller soybean plants than solid cultures number of branches and pods, as well as, seed yield per plant and fad were significantly decreased by intercropping soybean with maize, while, seed index was not significantly affected by cropping system.

Nitrogen $(\mathrm{N})$ is the most important element for plant growth and development. It is an integral component of many compounds essential for plant growth processes including chlorophyll and many enzymes. The optimal amounts of these elements in the solid cannot be utilized efficiency if nitrogen is deficient in plants.

El-Douby et al (1996) reported that ear length, ear diameter, number of grains/row, weight of 100 kernels, grain yield/ plant and faddan were significantly decreased by intercropping patterns as compared with maize alone. Soybean intercropping pattern significantly reduce plant height, number of branches and pods/plant, weight of pods and seeds/plant, whereas seed index were in significantly affected by the studied patterns.

Assey et al (1992 b) indicated that intercropping soybean with maize on the same ridge did not affect plant height, number of ears/plant, grain yield/plant and faddan of maize, while solid culture of maize surpassed intercropped maize with soybean in ear height, grains yield/ear, 100 grain weight, grain yield/fad and harvest index.

Kamel et al (1990) intercropping soybean with maize decreased significantly yield and yield components of soybean the plant height, number of branches, number pods, seed yield and number of seeds/plant, 100 seeds weight and seed yield/fad.

Abd El-Latef (1998) observed that intercropping maize and soybean increase the efficiency of land use by $38.0,37.0$ and $41.0 \%$ for the intercropping patterns $(2: 2, \quad 1: 2$ and $2: 4)$ respectively.

Mettwally et al (2005 a) reported that increasing maize densities and distributed maize in 4 plants/hill resulted in an increase 1.55 of LER. Similar results were obtained by Mettwally et al (2005 b). Moreover Toaima (2006) demonstrated that LER was significantly higher the ratio of $100 \%$ maize $+37.5 \%$ soybean El-Douby et al (1996) revealed that the highest LER values obtained by intercropping pattern of 100.0 maize $+67.0 \%$ soybean.

Moreover Metwally et al $\mathbf{( 2 0 0 5}$ b) reported that net return in alternating pattern was high when maize and groundnut were planted in density $100 \%$ increasing nitrogen application rates till $120 \mathrm{~kg} \mathrm{~N} /$ fad increased biological yield/plant. These increasing may be due to the role of nitrogen in increasing the plant height and production of more metabolites that led to heavier grain weight and its contribution to higher yield/ plant.

The aim of this investigation increased the area planted soybean with intercropping in maize areas.

\section{Materials and Methods}

A field experiment was carried out at Sers ElLian Agriculture Research Station Menofiya. Governorate during the two successive summer seasons (2010 and 2011) to study the effect of nitrogen fertilizer levels and intercropping pattern on yield and yield attributes of maize with soybean. The soil was clay in texture and had average of 0.18 for total $\mathrm{N} \%, 5.42$ and $346 \mathrm{ppm}$ for $\mathrm{p}$ and $\mathrm{k}$, respectively during the two seasons. The treatments were assigned in split plots design with three replications. The maize variety was (single cross 122), while soybean cultivar Giza 35 was used. Experimental plot area was $16.8 \mathrm{~m}^{2}$ consisting of 8 ridges $3 \mathrm{~m}$ long a $70 \mathrm{~cm}$ wide for solid and intercropped plantings. Main plots included three nitrogen fertilizer levels: (90, 105 and $120 \mathrm{~kg} \mathrm{~N} /$ fad.). Sub-plots included three intercropping patterns for soybean with maize as follows:-

$\left(\mathrm{P}_{1}\right)$ maize intercropped was planted in the whole plot (8 ridges) in hills $50 \mathrm{~cm}$ apart and leaving 2 plants/hill, while soybean was planted on two ridges number 1 and 8 to give (100\% maize+ $25 \%$ soybean), $\left(\mathrm{P}_{2}\right)$ soybean was planted on four ridges 
number $1,2,7$ and 8 to give (100\% maize+ $50 \%$ soybean) and $\left(\mathrm{P}_{3}\right)$ soybean planted on six ridges number $1,2,3,6,7$ and 8 in hills $10 \mathrm{~cm}$ apart and leaving 2 plants/hill at the other side of maize ridges in all intercropping patterns to give (100\% maize+ $75 \%$ soybean).

The solid maize was planted in hills $25 \mathrm{~cm}$ apart and leaving one plant/hill. The solid soybean was planted in hills $20 \mathrm{~cm}$ apart on the two sides and leaving 2 plants/hill. Maize was sown in 3 and 5 June at 2010 and 2011, respectively, while soybean was sown 15 days before maize.

Calcium superphosphate at the rate was $30 \mathrm{~kg}$ $\mathrm{P}_{2} \mathrm{O}_{5} /$ fad. (15.5\% $\left.\mathrm{P}_{2} \mathrm{O}_{5}\right)$ was added during soil preparation. Nitrogen fertilizer of maize was $120 \mathrm{~kg}$ $\mathrm{N} /$ fad. in the form of ammonium nitrate $(33.5 \% \mathrm{~N})$ three equal doses were added every 15 days the first one was added after thinning (20 days after sowing). Potassium fertilizer was $24 \mathrm{~kg} \mathrm{~K}_{2} \mathrm{O} /$ fad. potassium sulphate $\left(48 \% \mathrm{~K}_{2} \mathrm{O}\right)$ divided into two equal doses the first dose was added immediately after thinning and the second after 15 days later. Soybean seeds were inoculated with specific bacteria (Bradyrhizobium japonicum L.) at sowing time and the preceding crops sugar beet and faba bean in the first and the second seasons, respectively.

Studied characters: maize characters plant height $(\mathrm{cm})$, ear height $(\mathrm{cm})$, ear diameter $(\mathrm{cm})$, ear length $(\mathrm{cm})$, number of rows ear, ear weight $(\mathrm{g}), 100$ seed weight (g) and grain yield/fad. (ardab).

Soybean characters: plant height $(\mathrm{cm})$, number of branches/plant, number of pods/plant, number of seeds/plant, seed yield/ plant (g), 100 seed weight (g) and seed yield (kg/fad.).

\section{Competitive relationships}

1. Land equivalent ratio (LER): according to Willey \& Osiru, 1972).

$\mathbf{L E R}=\left(\mathrm{Y}_{\mathrm{ab}} / \mathrm{Y}_{\mathrm{aa}}\right)+\left(\mathrm{Y}_{\mathrm{ba}} / \mathrm{Y}_{\mathrm{bb}}\right)$

\section{Aggressivity (Agg).}

This was proposed by Mc-Gilichrist (1965) and was determined according to the following formula:

$\mathrm{Ag}_{\mathrm{a}}=\left[\mathrm{Y}_{\mathrm{ab}} /\left(\mathrm{Y}_{\mathrm{aa}} \times \mathrm{Z}_{\mathrm{ab}}\right)\right]-\left[\mathrm{Y}_{\mathrm{ba}} /\left(\mathrm{Y}_{\mathrm{bb}} \times \mathrm{Z}_{\mathrm{ba}}\right)\right] \mathrm{Ag}_{\mathrm{b}}$ $=\left[\mathrm{Y}_{\mathrm{ba}} /\left(\mathrm{Y}_{\mathrm{bb}} \times \mathrm{Z}_{\mathrm{ba}}\right)\right]-\left[\mathrm{Y}_{\mathrm{ab}} /\left(\mathrm{Y}_{\mathrm{aa}} \times \mathrm{Z}_{\mathrm{ab}}\right)\right]$

An aggressivity value of zero indicates that the intercropped crops are equally competitive for any other situation both crops will have the same numerical value, but the sign of the dominant crop is positive and the dominated is negative.

\section{Competitive ratio (CR) by Willey and Rao (1980).}

\section{$\mathbf{C R a}=\left\{\left(\frac{L E R a}{L E R b}\right) \times\left(\frac{Z b a}{Z a b}\right)\right\}, \quad \mathbf{C R b}=$ $\left\{\left(\frac{L E R b}{L E R a}\right) \times\left(\frac{Z a b}{Z b a}\right)\right\}$}

4. Land equivalent coefficient (LEC)

$\mathbf{L E C}=\mathrm{La} \times \mathrm{Lb} \quad \mathrm{La}=\mathrm{LER}$ of main crop $\quad \mathrm{Lb}$ $=$ LER of intercrop

LEC however, measures acceptable level competitive interaction confers sufficient degree of complementarily (i-e it indicates the minimum level of reasonable contribution by the least productive intercrop component) if a yield advantage is indicated Adetiloye et al, (1983). For a two crop mixture the minimum expect productivity coefficient is $25 \%$ i-e a yield advantage is obtained if LEC value exceeds 0.25 .

\section{Economic evaluation:}

Monetary advantage index (MAI): Suggests that the economic assessment should be in terms of the value of land saved; this could probably be most assessed on the basis of the rentable value of this land. MAI was calculated according to the formula, suggested by Willey (1979).

\section{MAI}

$$
=\frac{\text { Value of combined intercrop } \mathrm{s} \times \mathrm{LER}-1}{L E R}
$$

6. Monetary Equivalent Ratio (MER): MER was calculated according to the formula, suggested by Adetiloye and Adekunle (1989).

$$
\mathbf{M E R}=\frac{\mathrm{ra}+\mathrm{rb}}{\mathrm{Ra}}
$$

Where as: ra \& rb monetary returns from (a) and (b), Ra. highest sole crop monetary return, ra = $\mathrm{pa} \times \mathrm{ya}, \mathrm{rb}=\mathrm{pb} \times \mathrm{yb}, \quad \mathrm{ya} \& \mathrm{yb}$ yield of $\mathrm{a}$ and $\mathrm{b}$, $\mathrm{pa}, \mathrm{pb}$ prices of unit weight of crop $\mathrm{a}$ and $\mathrm{b}$

\section{Gross return (LE/fad):}

Gross return from each treatment was calculated in Egyptian pounds (LE) at market prices which were 262 or 270 LE for maize ardab/fad., 2316 or $2866 \mathrm{LE}$ for soybean ton/ fad. in 2010 or 2011 seasons, respectively.

Data for each experiment were then analyzed by MISTATC (1980) software for comparison of the mean values of the two seasons by LSD test at the $5 \%$ level. Response equations were calculated according to Snedecor and Cochran (1988). 


\section{Results and Discussion}

1. Maize

a. Effect of nitrogen fertilization levels on growth yield and yield components of maize

Data in Table (1) indicated that yield and yield component of maize were significantly increased by increasing nitrogen fertilizer levels. Plant height of maize thegave the highest when fertilized level (120 $\mathrm{kg} \mathrm{N} /$ fad.), led to increase meristematic activity and stimulation to increase in elongation, while the lowest value was recorded with fertilized level $(90$ N/fad.).

Yield components of maize i-e. ear diameter, ear length, number of grain row, ear grain weight,
100 seed weight and grain yield take the same trend of plant height.

Ear grain weight was increased by increasing nitrogen fertilizer levels from 90 to $120 \mathrm{~kg} \mathrm{~N} / \mathrm{fad}$. The increased 16.86, 8.73 and $7.48 \%$ in the first season while the second season 16.10, 9.53 and $6.00 \%$ from increased nitrogen fertilizer levels from 90 to 120,90 to 105 and 105 to $120 \mathrm{~kg} \mathrm{~N} / \mathrm{fad}$., respectively. Grain yield/fad. increased by increasing nitrogen fertilizer levels from 90 to $120 \mathrm{~kg} \mathrm{~N} / \mathrm{fad}$. The increased were $11.14,3.66$ and $7.22 \%$ in first season while the second season $10.22,3.71$ and $6.27 \%$ from increased nitrogen fertilizer levels from 90 to 120,90 to 105 and 105 to $120 \mathrm{~kg} \mathrm{~N} / \mathrm{fad}$., respectively. The same trend was reported by Metwally et al (2005 b).

Table 1. Effect of nitrogen fertilization levels on yield and yield components of maize in the first and the second seasons.

\begin{tabular}{|c|c|c|c|c|c|c|c|c|}
\hline \multicolumn{9}{|c|}{ First season 2010} \\
\hline $\begin{array}{l}\text { Nitrogen } \\
\text { fertilizer }\end{array}$ & $\begin{array}{c}\text { Plant } \\
\text { height } \\
(\mathrm{cm})\end{array}$ & $\begin{array}{c}\text { Ear } \\
\text { height } \\
(\mathrm{cm})\end{array}$ & $\begin{array}{c}\text { Ear } \\
\text { diameter } \\
(\mathbf{c m})\end{array}$ & $\begin{array}{c}\text { Ear } \\
\text { length } \\
(\mathrm{cm})\end{array}$ & $\begin{array}{c}\text { No.of } \\
\text { rows } \\
\text { ear }\end{array}$ & $\begin{array}{c}\text { Ear } \\
\text { weight } \\
\text { (g) }\end{array}$ & $\begin{array}{c}100 \text { seed } \\
\text { weight } \\
\text { (g) }\end{array}$ & $\begin{array}{c}\text { Grain } \\
\text { yield/ } \\
\text { fad. } \\
\text { (ardab) }\end{array}$ \\
\hline 90 & 277.2 & 136.20 & 4.14 & 20.27 & 13.02 & 187.11 & 36.73 & 17.50 \\
\hline 105 & 280.7 & 139.77 & 4.30 & 21.22 & 14.32 & 203.45 & 38.83 & 18.14 \\
\hline 120 & 284.8 & 141.13 & 4.47 & 22.76 & 15.44 & 218.67 & 39.81 & 19.45 \\
\hline LSD $5 \%$ & 1.72 & 3.68 & 0.04 & 0.33 & 0.15 & 3.14 & 0.12 & 0.60 \\
\hline solid & 285.2 & 145.0 & 4.60 & 23.10 & 16.0 & 220.0 & 41.0 & 22.0 \\
\hline \multicolumn{9}{|c|}{ Second season 2011} \\
\hline 90 & 279.10 & 138.00 & 4.24 & 21.08 & 13.71 & 199.34 & 38.48 & 18.60 \\
\hline 105 & 282.20 & 140.10 & 4.43 & 22.14 & 14.69 & 218.33 & 39.47 & 19.29 \\
\hline 120 & 287.43 & 143.43 & 4.64 & 23.32 & 15.58 & 231.44 & 40.62 & 20.50 \\
\hline LSD $5 \%$ & 1.99 & 1.47 & 0.02 & 0.18 & 0.22 & 4.06 & 0.25 & 0.61 \\
\hline solid & 290.0 & 150.0 & 4.70 & 24.0 & 16.2 & 240.1 & 43.0 & 23.0 \\
\hline
\end{tabular}

b. Effect of intercropping patterns soybean on yield and yield components of maize.

Data presented in Table (2) showed that all characters under study of maize were significantly affected by different plant density of soybean in both seasons.

Plant height recorded the highest value with intercropping pattern ( $100 \%$ maize $+25 \%$ soybean), while the lowest value was recorded with intercropping pattern ( $100 \%$ maize $+75 \%$ soybean) in both seasons.

Yield components of maize i-e ear height, ear diameter, ear length, number of grains/row, ear grain weights, 100 seed weight and grain yield/fad. behaved as the same trend of plant height. Ear grain weight was decreased by increasing plant density of soybean from $25 \%$ to $75 \%$. The decrease percentage were $10.16,5.75$ and $4.67 \%$ in the first season while in the second season were recorded $11.23,7.23$ and $4.31 \%$ from increasing plant density of soybean from $25 \%$ to $75 \%, 25 \%$ to $50 \%$ and $50 \%$ to $75 \%$, respectively. The decrease in grain yield/fad. was probably due to the decrease number of row per ear, number of grain per row and 100 seed weight..... etc. the decrease of grain yield/fad to plant density soybean from $25 \%$ to $75 \%$ were $2.63,1.5$ and 1.15 in the first season, while in the second season were recorded 2.24, 1.02 and $0.98 \%$ from plant density soybean $25 \%$ to $75 \%, 25 \%$ to $50 \%$ and $50 \%$ to $75 \%$, respectively. Similar results were obtained by ElDouby et al (1996) and Solank et al (2011). 
Table 2. Effect of intercropping patterns on yield and yield components of maize in the first and the second seasons.

\begin{tabular}{|c|c|c|c|c|c|c|c|c|}
\hline \multicolumn{9}{|c|}{ First season 2010} \\
\hline $\begin{array}{c}\text { Intercropping } \\
\text { patterns }\end{array}$ & $\begin{array}{c}\text { Plant } \\
\text { height } \\
(\mathrm{cm})\end{array}$ & $\begin{array}{c}\text { Ear } \\
\text { height } \\
(\mathbf{c m})\end{array}$ & $\begin{array}{c}\text { Ear } \\
\text { diameter } \\
(\mathbf{c m})\end{array}$ & $\begin{array}{l}\text { Ear length } \\
\quad(\mathrm{cm})\end{array}$ & $\begin{array}{c}\text { No.of } \\
\text { rows } \\
\text { ear }\end{array}$ & $\begin{array}{c}\text { Ear } \\
\text { weight } \\
\text { (g) }\end{array}$ & $\begin{array}{c}100 \\
\text { seed } \\
\text { weight } \\
(\mathrm{g})\end{array}$ & $\begin{array}{c}\text { Grain } \\
\text { yield/ } \\
\text { fad. } \\
\text { (ardab) }\end{array}$ \\
\hline $100+25 \%$ & 276.8 & 141.57 & 4.38 & 22.28 & 14.66 & 214.45 & 40.17 & 18.62 \\
\hline $100+50 \%$ & 281.4 & 138.67 & 4.31 & 21.34 & 14.30 & 202.11 & 37.99 & 18.34 \\
\hline $100+75 \%$ & 284.4 & 136.87 & 4.23 & 20.62 & 13.82 & 192.67 & 37.22 & 18.13 \\
\hline LSD $5 \%$ & 1.39 & 1.43 & 0.03 & 0.21 & 0.19 & 1.31 & 0.14 & 0.22 \\
\hline solid & 280.2 & 145.0 & 4.60 & 23.10 & 16.0 & 220.0 & 41.0 & 22.0 \\
\hline \multicolumn{9}{|c|}{ Second season 2011} \\
\hline $100+25 \%$ & 279.7 & 143.87 & 4.52 & 23.16 & 15.42 & 230.56 & 40.83 & 19.66 \\
\hline $100+50 \%$ & 282.3 & 140.77 & 4.43 & 22.19 & 14.79 & 213.89 & 39.42 & 19.46 \\
\hline $100+75 \%$ & 286.8 & 136.90 & 4.36 & 21.20 & 13.76 & 204.67 & 39.31 & 19.27 \\
\hline LSD $5 \%$ & 1.23 & 0.98 & 0.03 & 0.17 & 0.09 & 1.96 & 0.14 & 0.20 \\
\hline Solid & 282.0 & 150.0 & 4.70 & 24.0 & 16.2 & 240.1 & 43.0 & 23.0 \\
\hline
\end{tabular}

c. Effect of the interaction between intercropping patterns soybean and nitrogen fertilizer levels on yield and yield components of maize.

Maize characters plant height, ear diameter, ear length, number of grains/row, ear weight and 100 seed weight which decreased due to increasing plant density soybean and inter and intra competition between plant for light, water, nutrientsintercropping pattern $\times$ nitrogen fertilizer levels as shown in Table (3) the highest values for all previous character of maize recorded nitrogen fertilizer level $120 \mathrm{~kg} \mathrm{~N} / \mathrm{fad}$. and plant density of soybean (25\%), whereas intercropping plant density of soybean $75 \%$ and nitrogen fertilizer level $90 \mathrm{~N} / \mathrm{fad}$. give the lowest of these characters. This result may be due to the decrease in plant density of soybean intercropped with maize from $25 \%$ to $75 \%$ which decreased inter and intra competition between plants for light, water, nutrients... etc.

Table 3. Effect of the interaction between intercropping patterns and nitrogen fertilizer levels on yield and yield components of maize in the first and the second seasons

\section{First season 2010}

\begin{tabular}{|c|c|c|c|c|c|c|c|c|c|}
\hline 离 & $\begin{array}{c}\text { Intercropping } \\
\text { patterns }\end{array}$ & $\begin{array}{l}\text { Plant } \\
\text { height } \\
(\mathbf{c m})\end{array}$ & $\begin{array}{c}\text { Ear } \\
\text { height } \\
(\mathbf{c m})\end{array}$ & $\begin{array}{c}\text { Ear } \\
\text { length } \\
(\mathrm{cm})\end{array}$ & $\begin{array}{c}\text { Ear } \\
\text { diameter } \\
(\mathbf{c m})\end{array}$ & $\begin{array}{l}\text { No.of } \\
\text { grain } \\
\text { row }\end{array}$ & $\begin{array}{l}\text { Ear } \\
\text { weight/ } \\
\text { plant } \\
\text { (g) }\end{array}$ & $\begin{array}{l}100 \text { seed } \\
\text { weight } \\
(\mathrm{g})\end{array}$ & $\begin{array}{c}\text { Grain } \\
\text { yield/ } \\
\text { fad. } \\
\text { (ardab) }\end{array}$ \\
\hline 90 & $\begin{array}{l}100+25 \% \\
100+50 \% \\
100+75 \%\end{array}$ & $\begin{array}{l}275.0 \\
277.3 \\
279.3\end{array}$ & $\begin{array}{l}138.3 \\
136.0 \\
134.3\end{array}$ & $\begin{array}{l}21.23 \\
19.97 \\
19.60\end{array}$ & $\begin{array}{l}4.20 \\
4.16 \\
4.07\end{array}$ & $\begin{array}{l}13.71 \\
13.17 \\
12.17\end{array}$ & $\begin{array}{l}198.67 \\
189.33 \\
173.33\end{array}$ & $\begin{array}{l}38.07 \\
36.33 \\
35.80\end{array}$ & $\begin{array}{l}17.85 \\
17.43 \\
17.22\end{array}$ \\
\hline 105 & $\begin{array}{l}100+25 \% \\
100+50 \% \\
100+75 \%\end{array}$ & $\begin{array}{l}276.0 \\
281.7 \\
284.3\end{array}$ & $\begin{array}{l}142.7 \\
139.3 \\
137.3\end{array}$ & $\begin{array}{l}22.13 \\
21.33 \\
20.20\end{array}$ & $\begin{array}{l}4.38 \\
4.31 \\
4.22\end{array}$ & $\begin{array}{c}14.5 \\
14.37 \\
14.10\end{array}$ & $\begin{array}{l}216.67 \\
198.67 \\
195.00\end{array}$ & $\begin{array}{l}40.53 \\
38.33 \\
37.63\end{array}$ & $\begin{array}{l}18.36 \\
18.10 \\
17.95\end{array}$ \\
\hline 120 & $\begin{array}{l}100+25 \% \\
100+50 \% \\
100+75 \%\end{array}$ & $\begin{array}{l}279.3 \\
285.3 \\
289.7\end{array}$ & $\begin{array}{l}143.7 \\
140.7 \\
139.0\end{array}$ & $\begin{array}{l}23.47 \\
22.73 \\
22.07\end{array}$ & $\begin{array}{l}4.56 \\
4.45 \\
4.46\end{array}$ & $\begin{array}{l}15.77 \\
15.37 \\
15.18\end{array}$ & $\begin{array}{l}228.00 \\
218.33 \\
208.67\end{array}$ & $\begin{array}{l}41.90 \\
39.30 \\
38.23\end{array}$ & $\begin{array}{l}19.65 \\
19.48 \\
19.21\end{array}$ \\
\hline & $\begin{array}{l}\text { LSD 5\% } \\
\text { solid } \\
\end{array}$ & $\begin{array}{c}2.09 \\
280.2\end{array}$ & $\begin{array}{c}3.0 \\
145.0\end{array}$ & $\begin{array}{l}0.36 \\
4.60 \\
\end{array}$ & $\begin{array}{c}0.10 \\
23.10\end{array}$ & $\begin{array}{l}0.33 \\
16.0 \\
\end{array}$ & $\begin{array}{c}2.27 \\
220.0\end{array}$ & $\begin{array}{l}0.24 \\
41.0 \\
\end{array}$ & $\begin{array}{l}\text { NS } \\
22.0\end{array}$ \\
\hline \multicolumn{10}{|c|}{ Second season 2011} \\
\hline 90 & $\begin{array}{l}100+25 \% \\
100+50 \% \\
100+75 \% \\
\end{array}$ & $\begin{array}{l}276.0 \\
279.3 \\
282.0 \\
\end{array}$ & $\begin{array}{l}141.3 \\
138.0 \\
134.7\end{array}$ & $\begin{array}{l}22.27 \\
21.17 \\
19.80\end{array}$ & $\begin{array}{l}4.32 \\
4.22 \\
4.17\end{array}$ & $\begin{array}{l}14.15 \\
13.85 \\
13.12\end{array}$ & $\begin{array}{l}211.67 \\
196.67 \\
189.67\end{array}$ & $\begin{array}{l}39.83 \\
38.37 \\
37.23\end{array}$ & $\begin{array}{l}18.75 \\
18.65 \\
18.40\end{array}$ \\
\hline
\end{tabular}




\begin{tabular}{cccccccccc}
\hline \multirow{3}{*}{$\mathbf{1 0 5}$} & $\mathbf{1 0 0 + 2 5 \%}$ & 279.0 & 143.0 & 23.00 & 4.53 & 15.60 & 235.00 & 41.00 & 19.53 \\
& $\mathbf{1 0 0 + 5 0 \%}$ & 280.7 & 140.3 & 22.10 & 4.43 & 14.83 & 215.00 & 39.23 & 19.23 \\
& $\mathbf{1 0 0 + 7 5 \%}$ & 287.0 & 137.0 & 21.33 & 4.33 & 13.63 & 205.00 & 38.17 & 19.12 \\
& $\mathbf{1 0 0 + 2 5 \%}$ & 284.0 & 147.3 & 24.20 & 4.72 & 16.52 & 245.00 & 41.67 & 20.71 \\
\multirow{2}{*}{$\mathbf{1 2 0}$} & $\mathbf{1 0 0 + 5 0 \%}$ & 287.0 & 144.0 & 23.30 & 4.64 & 15.70 & 230.00 & 40.67 & 20.49 \\
& $\mathbf{1 0 0 + 7 5 \%}$ & 291.3 & 139.0 & 22.47 & 4.57 & 14.53 & 219.33 & 39.53 & 20.30 \\
\hline \multirow{2}{*}{ LSD 5\% } & 4.50 & 5.0 & 0.29 & 0.04 & 0.15 & 3.40 & 0.25 & NS \\
\hline & Solid & 282.0 & 150.0 & 4.70 & 24.0 & 16.2 & 240.1 & 43.0 & 23.0 \\
\hline
\end{tabular}

\section{2 - Soybean}

a. Effect of nitrogen fertilizer levels on yield and yield components of soybean.

Results of the present in Table (4) showed that all characters under study of soybean were significantly by nitrogen fertilizer levels in both seasons.

Plant height of soybean recorded the highest value when adding $120 \mathrm{~kg} \mathrm{~N} / \mathrm{fad}$. Whereas the lowest values was showed when nitrogen fertilizer level $90 \mathrm{~kg} \mathrm{~N} / \mathrm{fad}$. The increased some characters of soybean yield component i-e number of branches, pods/plant, weight seed yield/plant and 100 seeds and seed weight in both seasons as shown in (Table 4).
Seed yield/fad. of soybean as the same trend of yield components in both seasons as shown in Table (4). Seed yield fed of in all nitrogen fertilizer lower compared with solid in both seasons. The decreased were $10.46,5.98$ and $4.77 \%$ in the first season while were $15.05,7.40$ and $8.26 \%$ in the second season from 90 to 120,90 to 105 and 105 to $120 \mathrm{~kg} \mathrm{~N} / \mathrm{fad}$, respectively. Increasing nitrogen levels from 90 to $120 \mathrm{~kg} \mathrm{~N} /$ fad. Significantly increased all studied characters and this due to the important role of nitrogen in enhanced and activation in vegetative growth which led to increase in plant height and all characters.

Similar results were observed by Shivay and Singh (2003) and Undie et al (2010).

Table 4. Effect of nitrogen fertilizer levels on yield and yield components of soybean in the first and the second seasons.

\begin{tabular}{cccccccc}
\hline & \multicolumn{3}{c}{ First season 2010 } & & \\
\hline $\begin{array}{c}\text { Nitrogen } \\
\text { fertilizer }\end{array}$ & $\begin{array}{c}\text { Plant } \\
\text { height } \\
\text { (cm) }\end{array}$ & $\begin{array}{c}\text { No.of } \\
\text { branches/ } \\
\text { plant }\end{array}$ & $\begin{array}{c}\text { No.of } \\
\text { pods/ } \\
\text { plant }\end{array}$ & $\begin{array}{c}\text { No.of } \\
\text { seeds/ } \\
\text { plant }\end{array}$ & $\begin{array}{c}\text { Seed } \\
\text { yield/ } \\
\text { plant } \\
\text { (g) }\end{array}$ & $\begin{array}{c}\text { 100 seed } \\
\text { weight } \\
\text { (g) }\end{array}$ & $\begin{array}{c}\text { Seed } \\
\text { yield/kg } \\
\text { fad. }\end{array}$ \\
\hline $\mathbf{9 0}$ & 107.0 & 1.26 & 21.95 & 53.99 & 8.27 & 15.18 & 659.00 \\
$\mathbf{1 0 5}$ & 115.5 & 1.82 & 23.61 & 57.38 & 8.71 & 15.78 & 692.33 \\
$\mathbf{1 2 0}$ & 117.7 & 2.42 & 25.78 & 62.85 & 9.02 & 16.18 & 736.00 \\
\hline LSD 5\% & 2.24 & 0.15 & 0.55 & 1.53 & 0.25 & 0.14 & 32.7 \\
\hline solid & 122.0 & 2.2 & 26.0 & 53.0 & 12.0 & 18.0 & 1420 \\
\hline $\mathbf{9 0}$ & & & Second season $\mathbf{2 0 1 1}$ & & & \\
\hline $\mathbf{1 0 5}$ & 104.4 & 1.47 & 23.44 & 55.81 & 8.39 & 15.56 & 666.33 \\
\hline $\mathbf{1 2 0}$ & 113.1 & 2.13 & 25.01 & 59.58 & 9.05 & 16.21 & 726.66 \\
\hline LSD 5\% & 114.3 & 2.53 & 27.07 & 65.18 & 9.48 & 16.62 & 784.00 \\
\hline Solid & 2.22 & 0.15 & 0.44 & 1.50 & 0.50 & 0.09 & 52.8 \\
\hline
\end{tabular}

b. Effect of intercropping patterns on yield and yield components of soybean.

Table (5) shows that intercropping soybean with maize percentage $25 \%, 50 \%$ and $75 \%$ were significantly of all characters under study in both seasons.

Plant height of soybean recorded the highest value when maize was intercropped at the other side of all ridge $100 \%$ maize $+75 \%$ soybean and the lowest value was showed when $100 \%$ maize+ $25 \%$ soybean. This results may be due to inter and intra competition between plant of soybean and maize for light.

Reducing population of soybean from 75 to 50 to $25 \%$ by planting soybean at the other side of all maize ridges increased same characters of soybean, yield components i-e, number of branches, pods, 
seeds and seed yield/plant, seed index and seed yield/fad. in both seasons as shown in Table (5).

The increase seed yield/fad. of soybean by increasing plant density from $25 \%$ to $50 \%$ were
$43.13 \%$ and $40.37 \%$, while $50 \%$ to $75 \%$ were $43.03 \%$ and $43.21 \%$ in the first and the second seasons, respectively.

Table 5. Effect of intercropping patterns on yield and yield components of soybean in the first and the second seasons.

\begin{tabular}{cccccccc}
\hline & \multicolumn{7}{c}{ First season 2010 } \\
\hline $\begin{array}{c}\text { Intercropping } \\
\text { patterns }\end{array}$ & $\begin{array}{c}\text { Plant } \\
\text { height } \\
\text { (cm) }\end{array}$ & $\begin{array}{c}\text { No.of } \\
\text { branches/ } \\
\text { plant }\end{array}$ & $\begin{array}{c}\text { No.of } \\
\text { pods/ } \\
\text { plant }\end{array}$ & $\begin{array}{c}\text { No.of } \\
\text { seeds/ } \\
\text { plant }\end{array}$ & $\begin{array}{c}\text { Seed } \\
\text { yield/plant } \\
\text { (g) }\end{array}$ & $\begin{array}{c}\text { 100 seed } \\
\text { weight } \\
\text { (g) }\end{array}$ & $\begin{array}{c}\text { Seed } \\
\text { yield/kg } \\
\text { fad. }\end{array}$ \\
\hline $\mathbf{1 0 0 + 2 5 \%}$ & 108.1 & 2.11 & 25.23 & 61.47 & 9.12 & 16.09 & 465.66 \\
$\mathbf{1 0 0 + 5 0 \%}$ & 112.9 & 1.79 & 23.55 & 57.38 & 8.59 & 15.69 & 667.00 \\
$\mathbf{1 0 0 + 7 5 \%}$ & 119.1 & 1.66 & 22.62 & 55.37 & 8.36 & 15.36 & 954.33 \\
LSD 5\% & 1.43 & 0.12 & 0.52 & 1.05 & 0.18 & 0.10 & 151.8 \\
Solid & 122.0 & 2.2 & 26.0 & 53.0 & 12.0 & 18.0 & 1420 \\
\hline $\mathbf{1 0 0 + 2 5 \%}$ & 106.0 & 2.38 & 26.49 & 63.48 & 9.48 & 16.54 & 493.00 \\
$\mathbf{1 0 0 + 5 0 \%}$ & 110.4 & 1.98 & 25.32 & 59.39 & 8.91 & 16.12 & 692.33 \\
$\mathbf{1 0 0 + 7 5 \%}$ & 115.5 & 1.78 & 23.68 & 57.70 & 8.53 & 15.72 & 990.66 \\
LSD 5\% & 1.55 & 0.10 & 0.42 & 0.98 & 0.19 & 0.13 & 145.9 \\
\hline Solid & 118.2 & 2.50 & 30.0 & 60.0 & 13.0 & 18.2 & 1530 \\
\hline
\end{tabular}

c. Effect of the interaction between nitrogen fertilizer levels and intercropping patterns on yield and yield components of soybean.

All characters of soybean were affected significantly by the interactions among, nitrogen fertilizer levels and intercropping patterns except number of branches/ plant.

The results Table (6) showed that the highest values of plant height and seed yield/fad. were recorded with nitrogen fertilizer levels $120 \mathrm{~kg} \mathrm{~N} / \mathrm{fad}$. and intercropping patterns $(100 \%$ maize $+75 \%$ soybean) and the lowest values were showed with nitrogen fertilizer levels $90 \mathrm{~kg} \quad \mathrm{~N} / \mathrm{fad}$. and intercropping patterns ( $100 \%$ maize $+25 \%$ soybean) in both seasons.

The results indicated that the highest values of yield components i.e number of branches, pods and seeds/plant, seed yield/plant and 100 seed weight when soybean intercropped $25 \%+100 \%$ maize and nitrogen fertilizer by $120 \mathrm{~kg} \mathrm{~N} /$ fad. on the other hand, the lowest values for their traits were showed when soybean intercropped $25 \%+100 \%$ maize and nitrogen fertilizer by $90 \mathrm{~kg} \mathrm{~N} /$ fad. in both seasons.

Table (6): Effect of the interaction between nitrogen fertilizer levels and intercropping patterns on yield and yield components of soybean in the first and the second seasons.

\begin{tabular}{|c|c|c|c|c|c|c|c|c|}
\hline \multicolumn{9}{|c|}{ First season 2010} \\
\hline 总 & $\begin{array}{c}\text { Intercropping } \\
\text { patterns }\end{array}$ & $\begin{array}{c}\text { Plant } \\
\text { height } \\
(\mathrm{cm})\end{array}$ & $\begin{array}{c}\text { No.of } \\
\text { branches/ } \\
\text { plant }\end{array}$ & $\begin{array}{l}\text { No.of } \\
\text { pods/ } \\
\text { plant }\end{array}$ & $\begin{array}{l}\text { No.of } \\
\text { seeds/ } \\
\text { plant }\end{array}$ & $\begin{array}{c}\text { Seed } \\
\text { yield/ } \\
\text { plant } \\
(\text { g) }\end{array}$ & $\begin{array}{c}100 \text { seed } \\
\text { weight } \\
\text { (g) }\end{array}$ & $\begin{array}{c}\text { Seed } \\
\text { yield/kg } \\
\text { fad. }\end{array}$ \\
\hline \multirow{3}{*}{90} & $100+25 \%$ & 103.7 & 1.47 & 23.50 & 57.40 & 8.50 & 15.50 & 427 \\
\hline & $100+50 \%$ & 107.0 & 1.20 & 21.67 & 53.50 & 8.33 & 15.17 & 623 \\
\hline & $100+75 \%$ & 110.3 & 1.10 & 20.67 & 51.07 & 7.97 & 14.87 & 927 \\
\hline \multirow{3}{*}{105} & $100+25 \%$ & 109.0 & 2.17 & 25.00 & 60.20 & 9.20 & 16.03 & 457 \\
\hline & $100+50 \%$ & 115.7 & 1.80 & 23.27 & 56.77 & 8.57 & 15,80 & 667 \\
\hline & $100+75 \%$ & 121.7 & 1.50 & 22.57 & 55.17 & 8.57 & 15.50 & 953 \\
\hline
\end{tabular}




\begin{tabular}{|c|c|c|c|c|c|c|c|c|}
\hline & $100+25 \%$ & 111.7 & 2.70 & 27.50 & 66.80 & 9.67 & 16.73 & 513 \\
\hline \multirow[t]{4}{*}{120} & $100+50 \%$ & 116.0 & 2.37 & 25.70 & 61.87 & 8.87 & 16.10 & 711 \\
\hline & $100+75 \%$ & 125.3 & 2.20 & 24.63 & 59.87 & 8.53 & 15.70 & 983 \\
\hline & LSD 5\% & 2.47 & NS & 0.50 & 1.95 & 0.31 & 0.17 & 140.0 \\
\hline & solid & 122.0 & 2.2 & 26.0 & 53.0 & 12.0 & 18.0 & 1420 \\
\hline \multicolumn{9}{|c|}{ Second season 2011} \\
\hline \multirow{4}{*}{90} & $100+25 \%$ & 102.0 & 1.77 & 24.70 & 58.93 & 8.60 & 15.93 & 433 \\
\hline & $100+50 \%$ & 104.3 & 1.40 & 23.30 & 55.47 & 8.40 & 15.57 & 633 \\
\hline & $100+75 \%$ & 107.0 & 1.23 & 22.33 & 53.03 & 8.17 & 15.17 & 933 \\
\hline & $100+25 \%$ & 108.0 & 2.50 & 26.40 & 62.63 & 9.60 & 16.80 & 513 \\
\hline \multirow[t]{3}{*}{105} & $100+50 \%$ & 112.7 & 2.10 & 25.23 & 58.87 & 8.93 & 16.13 & 681 \\
\hline & $100+75 \%$ & 118.7 & 1.80 & 23.33 & 57.23 & 8.63 & 15.70 & 983 \\
\hline & $100+25 \%$ & 109.0 & 2.87 & 28.37 & 68.87 & 10.23 & 16.90 & 533 \\
\hline \multirow[t]{2}{*}{120} & $100+50 \%$ & 114.3 & 2.43 & 27.43 & 63.87 & 9.40 & 16.67 & 763 \\
\hline & $100+75 \%$ & 119.7 & 2.30 & 25.40 & 62.83 & 8.80 & 16.30 & 1056 \\
\hline & LSD 5\% & 2.69 & NS & 0.90 & 0.95 & 0.33 & 0.23 & 170.0 \\
\hline & Solid & 118.2 & 2.50 & 30.0 & 60.0 & 13.0 & 18.2 & 1530 \\
\hline
\end{tabular}

Competitive relationships and yield advantage as affected by nitrogen fertilizer levels and intercropping patterns.

\section{Land equivalent ratio (LER)}

Data given in Table (7) show that total LER was higher at $100 \%$ maize $75 \%+$ soybean and nitrogen fertilizer $120 \mathrm{~kg} \mathrm{~N} / \mathrm{fad}$. achieved $56 \%$ and $57 \%$ of their sole yields while the lowest values achieved $11 \%$ and $10 \%$ of their sole yields at $100 \%$ maize $+25 \%$ soybean and nitrogen fertilizer $90 \mathrm{~kg} \mathrm{~N} / \mathrm{fad}$. in the first and the second seasons, respectively.

LEC values greater than 0.25 derived from the expected maize $100 \%+$ soybean $50 \%$ and $75 \%$ LEC of the intercropping $100 \%$ maize + $25 \%$ soybean and nitrogen fertilizer $90 \mathrm{~kg} \mathrm{~N} / \mathrm{fad}$ decreased. LEC values 0.60 and 0.61 which greater than 0.25 was observed $100 \%$ maize + $75 \%$ soybean of solid and nitrogen fertilizer $120 \mathrm{~kg} \mathrm{~N} / \mathrm{fad}$. in the first and second seasons, respectively. These results showed complementarity in resource utilization by the intercrop component crop.LEC values also greater the 0.25 signifying yield advantage of the intercropping patterns.

\section{Aggressivity (Agg) and competitive ratio(CR)}

Aggressivity and competitive ratio were presented in Table (7) aggressivity revealed that value for soybean was dominanted (positive) while maize was dominated (negative). The ranged aggressivity maize were between $(0.08$ -
$0.69)$ and (0.05 - 0.61) with cropping pattern $(100 \%$ maize +75 and $25 \%$ soybean) and nitrogen fertilizer level (120 kg N/fad.). The results that of $\mathrm{CR}$ corroborates aggressivity which showed that soybean was more competitive than maize. The range CR soybean was between $(1.62-1.60)$, while maize was between $(0.62-0.63)$ in the first and the second seasons, respectively.

\section{Monetary advantage index (MAI) monetary equivalent ratio (MER)}

The highest MAI values (2549.15 and 3088.71 ) were observed in $100 \%$ maize $+75 \%$ soybean of solid and nitrogen fertilizer $120 \mathrm{~kg}$ $\mathrm{N} / \mathrm{fad}$. while the lowest MAI values (559.78 and 573.04) were observed in $100 \%$ maize $+25 \%$ soybean of solid and nitrogen fertilizer $90 \mathrm{~kg} \mathrm{~N} / \mathrm{fad}$. in the first and the second seasons, respectively.

Monetary equivalent ratio (MER) defined as the ratio of intercrop monetary returns to the highest sole crop monetary return from the entire land area occupied by all intercrops per unit time. The intercrop was $100 \%$ maize with $75 \%$ soybean of solid and nitrogen fertilizer $120 \mathrm{~kg} \mathrm{~N} / \mathrm{fad}$. provided high MER 1.23 and 1.37 while the lowest MER values 0.98 and 1.02 was observed when intercrop $100 \%$ maize $+25 \%$ soybean of solid and nitrogen fertilizer $90 \mathrm{~kg} \mathrm{~N} / \mathrm{fad}$. in the first and the second seasons, respectively. MER values were greater than 1.00 thus signifying economic advantage of the intercrop system, 
Table 7. Competitive relationships and yield advantage as affected by nitrogen fertilizer levels and intercropping patterns in the first and the second seasons.

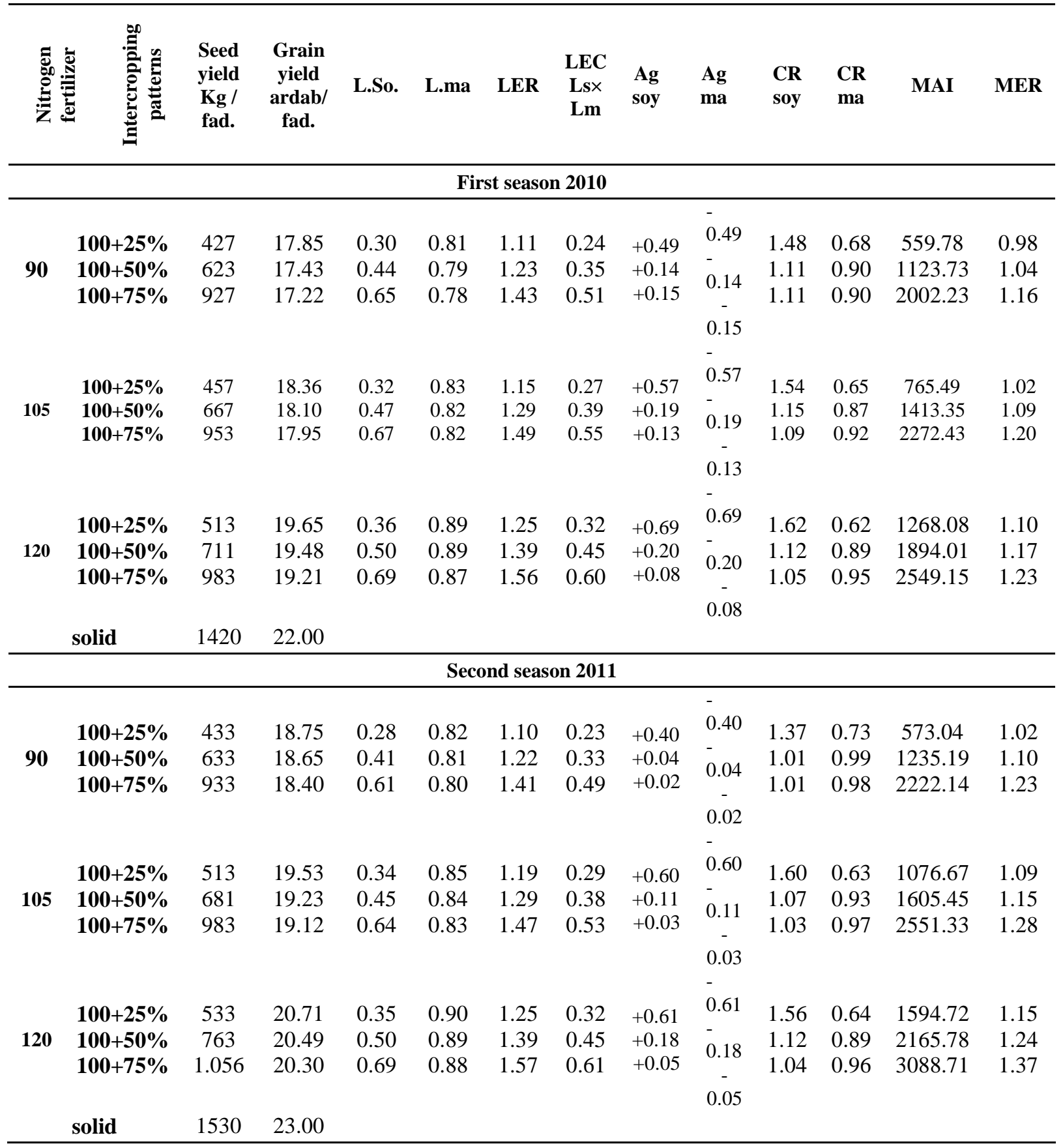

\section{References}

Abd El-Latef, E.A. (1988). Effect of some cultural practices on the intercropping of maize and soybean production. Ph.D.Thesis, Fac. Agric. Cairo Univ., Egypt.

Adetiloye P.O. and, A.A. Adekunle (1989). Concept of monetary equivalent ratio and its usefulness in the evaluation of intercropping advantages Trop. Agric. 66: 337-341.
Adetiloye, P.O:, F.O.C.Ezedima and B.N. Okigbo (1983). A land equivalent coefficient concept for the evaluation of competitive and productive interaction in simple to complex crop mixtures, Ecol. Modelling 19:27-39.

Agriculture Statistics (2011). Summer and Nile Crops. Agriculture Statistics and Economic Sector, 2 Ed.

Assey, A.A.; E.M.Zeidan, A.G.Eraky. M.A.Mohamed and A.A.Sarhan (1992 b). 
Intercropping soybean with maize 2-Effect of intercropping soybean plant population and $\mathrm{N}$ fertilization on yield and competitive relations of maize and soybean. Proc $5^{\text {th }}$ conf. Agron., Zagazig 13-15 Sept.Vol (2): 516-528.

El-Douby, K.A.; K.E.El-Habbak., H.E. Khalil and zahira. M. Attia (1996). Effect of some intercropping patterns on growth and yield of maize and soybean. Ann of Agric. Sci., Moshtohor. Vol 34(3): 919-933.

Francis. C.A.(1986). Distribution and importance of multiple cropping. Multiple Cropping system, Macmillam Publishing co.,new yourk, 1-19.

Kamel, A.S.; M.N.Sherif., M.A.El-Massry. S.K.Badr and M.H.Abd El-Aziz (1990).

Intercropping maize with soybean as influenced by different patterns. Agric. Res. Rev., 28:1-10.

Mc-Gillichrist,C.A. (1965). Analysis and Competition Experiments. Biometrics. 21: 975-985.

Mettwally, A.A. (1999). Intensive cropping system in the battle against food crises. Proc. $1^{\text {st }}$ Corn. Ph. D. Thesis, Fac. Agric., Cairo Univ.

Mettwally, A.A.; M.M.Shafik, M.Fayez and S.A.Safina (2007). Effect of nitrogen fertilization and diazotroph inoculation on yield of solids and intercropped maize with soybean. J. Agric. Sc., Mansoura Univ., 32(6): 4207-4215.

Mettwally, A.A.; Gamalat Mohamed O., M.N.Sherief and, Dina R. Abo-Hegazy (2009 a). Yield and land equivalent ratio of intercropped corn and soybean under three intercropping patterns. The $4^{\text {th }}$ Conf., Recent Technologies in Agric., 3-5 Nov., Cairo Univ., 2: 285-298.

Mettwally, A.A.; Gamalat Mohamed O., M.N. Sherief, and M.M. Awad (2005 b). Yield and equivalent ratio of intercropped maize and groundnut. The $11^{\text {th }}$ conf. Egypt Soc. Crop Sci, Assiut : 163-173.

MSTATC (1980). A Microcomputer Program of the Design Management and Analysis of Agronomic Research Experiments. Michigan State Univ., USA.
Panhwar, M.A.; F.H.Menon, M.A.Kalboro and M.I.Soorom (2004). Performance of maize in intercropping system with soybean under different planting patterns and nitrogen levels. J. of Appl. Sci., 4 (2): 201-204.

Snedecor,G.W. and W.G.Cochran (1988). Statistical Methods. $7^{\text {th }}$ Ed.Iowa State Univ. Press, Ames, Iowa, USA.

Solank, N.S.; D.Singh and H.K.Sumaria (2011). Resources utilization in maize (zea may L.) based intercropping system under rainfad contrition. Indian j. of Agric. Sci., 81 (6): 27 31.

Shivay, Y.; R.P.Singh (2003). Effect of nitrogen levels on productivity of grain legumes intercropped with maize (zea may L.) Lgume Res., 26 (4): 303-306.

Toaima, S.E.A. (2006). Effect of intercropping soybean, cowpea and guar with maize on yield and its components. J. Agric. Sci., Mansoura Univ., 31(1): 55-70.

Undie, U.L.; D.F.Uwab and E.E. Attoe (2010). The response of late season maize/ soybean intercropping to nitrogen in the humid environment of South Southern Nigeria J. of Agric. Forestry and Social Sci., 8(2):152165.

Undie, U.L.; D.F.Uwab and E.E. Attoe (2012). Growth and development of late season maize/soybean intercropping in response to nitrogen and crop arrangement in the forest Agro- ecology of South Southern Nigeria. Int. J. of Agric, Res., 7(1): 1-16.

Vega, C.R.; V.O. Sadras, F.H. Andrade and S.A. Uhart (2000). Reproductive all ometry in soybean, maize and sunflower. Ann. Bot. (London) 85: 461-468.

Willey, R. W. (1979). Intercropping, its importance and research needs. part1: Competition and yield advantages. Field Crops Abst. 32: 1 10.

Willey, R.W. and S.O.Osiru (1972). Studies on mixture of maize and beans (phasolus vulgaris) with particular reference to plant populations.J.Agric. Sci. Camb.79:519-529.

Willey, R. W. and M.R. Rao (1980). Competitive ratio for quantifying competition between intercrops. Exp. Agric. 16: 117-125. 


\section{تأثثر نظم التحميل ومستويات التسميد النيتروجيني على المحصول ومكوناته لكل من الأرة وفول الصويا المحملين}

رأفت عايد جاد الله - *عادل مجدى جبرة

قسم بحوث التكثيف المحصولي - ققم بحوث المحاصيل البقولية - معهد بحوث المحاصبل الحقلية - مركز البحوث

$$
\text { الزراعية - الجيزة - مصر }
$$

الملخص العريى

أجريت تجربة حقلية في محطة بحوث سرس الليان بمحافظة المنوفية خلا صيفى 2010 و 2011 لدراسة تأثيرمستويات التسميد النبتروجينى ونظم التحميل على محصولى الذرة وفول الصويا المحملين0 وكان التصميم المستخدم هو القطع المنشقة مرة واحدة فى ثلاثة مكررات 0 واحتوت القطع الرئيسية على ثلاثة مستويات من التسميد النيتروجينى 90 و 105 و 120 وحدة أزوت للفدان واحتوت القطع الثقية على ثلاثة نظم تحميل

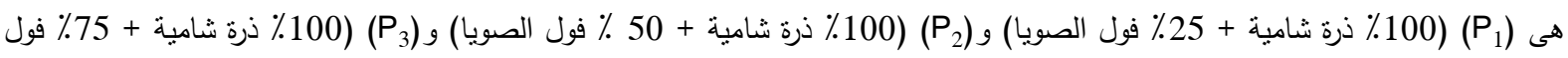
الصوبا). ويمكن تلخيص النتائج على النحو التالى: زاد محصول الذرة الثنامية للفدان بزيادة مستويات التسميد النيتروجينى0 بينما انخفض المحصول بزيادة كثافة فول الصويا من 25-75\% 0 زاد

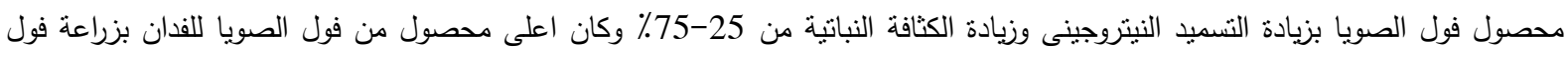

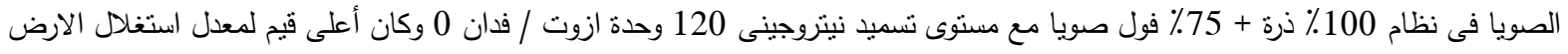
1,56 و 1,57 بينما اعلى معدل تتافس (LER) (LER) تسميد 120 وحدة ازوت/ فدان خلد الموسم الأول والثانى على التوالى0 اظهرت العدوانية ان فول الصويا هو السائد بينما الذرة الثامية هى المسود0 وكان محصول فول الصويا أعلى فى معدل التتافس (CR) بينما الذرة الثامية أقل فى معدل التتافسئس وكان أعلى قيم لدليل العائد

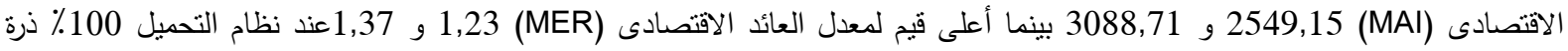
شامية + 75٪ فول الصويا مع مستوى نسميد 120 وحدة أزوت / فدان فى العام الأول والثانى على النوالى. 